\title{
Overview of Self Leadership during the COVID-19 Pandemic
}

\section{A A Ngurah Bagus Aristayudha ${ }^{1 *}$, Ni Made Widyani², Vitalia Fina Carla Rettobjaan ${ }^{3}$}

\author{
1,2 Universitas Bali Internasional, Bali, Indonesia
}

\section{A R T I C L E IN F O}

Article history:

Received August 16, 2021

Revised August 18, 2021

Accepted October 20, 2021

Available online November 25, 2021

\section{Keywords:}

Pandemic, Self Leadership, Enterpreneur, Business, Employee

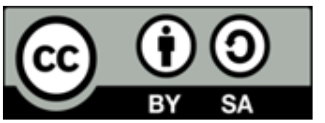

This is an open access article under the CC BY-SA license.

Copyright $(2021$ by Author. Published by Universitas Pendidikan Ganesha.

\begin{abstract}
A B S T R A C T
During the current covid-19 crisis, Bali's economic growth in 2020 shows that economic conditions in Bali are not going well. It makes organizational/company leaders adapt new strategies to survive the pandemic crisis. The behavior of leaders during a crisis will shape their qualifications as a good leader or a bad leader. Therefore, leaders must integrate this problem through a different approach than before. The purpose of this study was to analyze the differences in Self Leadership in entrepreneurial organizations, entrepreneurial individuals, nonentrepreneurial organizations, and non-entrepreneurial individuals. This research was conducted in Financial Evolution Bali with its members as respondents. The number of samples in this study was 90 respondents and used the Cluster Sampling method. The analytical technique used in this study is a different test analysis technique. Based on the analysis, it can be seen that there are differences in Self Leadership between organizational entrepreneurs and individual entrepreneurs. There are differences in SelfLeadership between organizational non-entrepreneurs and individual nonentrepreneurs. There are differences in Self Leadership between entrepreneurial organizations and non-entrepreneurial organizations. There are differences in Self Leadership between individual entrepreneurs and non-individual entrepreneurs. These differences can occur due to various factors, including the mindset, responsibilities, and burdens of each group.
\end{abstract}

\section{INTRODUCTION}

During the current covid-19 crisis, Bali's economic growth in 2020 indicates that economic conditions in the province of Bali are not doing well (Ardan et al., 2020; Paramita \& Putra, 2020; Sari et al., 2021). Leaders of organizations/companies especially those engaged in accommodation and food and beverage must adapt new strategies to survive the COVID-19 pandemic crisis (Hao et al., 2020; PedrozaGutiérrez et al., 2021). One organization that provides services or education on how to lead and manage a business to survive in this crisis situation is Financial Evolution Bali. Financial Evolution Bali or often called Fin.E is a coworking space startup that provides additional value by teaching financial literacy and education to the public, not only large organizations but also employees or MSMEs. The lessons provided range from financial education, management, business, stocks, to taxes. Lessons are given on a monthly basis, and have been running for more than 2 years. During this pandemic, Financial Evolution Bali continues to consistently carry out learning every month. Users of Financial Evolution Bali are mostly entrepreneurs and leaders of companies/organizations in the Province of Bali. Leadership skills are often put to the test in times of crisis (Andersen \& Watkins, 2018; Durnali, 2020; Richard et al., 2019).

Leaders' behavior during a crisis will shape their qualifications as a good leader or a bad leader (Klebe et al., 2021; Tuan, 2021). Therefore there is no manual available to guide leaders through the crisis. Because, while there are certain ways to prevent crises from occurring, each new crisis is unique, has its own problems and quirks, and will require a different approach than the previous one (Medeiros et al., 2022; Tao et al., 2022). Often, unpredictable crises leave leaders with little time to prepare. This is a situation that must be resolved or destroyed. Moreover, no one knows how long this crisis will last (AllalChérif et al., 2021; Chen et al., 2022). The timeframe can vary from a day or two to several years. The global economic crisis due to the corona virus pandemic or Covid-19 was not only felt in Indonesia but also globally. Crisis is an unpredictable thing like what is happening now is the Covid 19 pandemic (Anastasiou et al., 2021; Chan \& Abdul-Aziz, 2017; Syahria, 2020). This means that a crisis is an unstable state for an organization and can lead to unintended consequences (Van Lancker \& Parolin, 2020; Wei et al., 2019). 
Crisis is an unexpected, dramatic, sometimes unprecedented event that pushes an organization into chaos and can destroy it without real action. Crisis has no boundaries and can occur anytime, anywhere in any organization (Amrhein et al., 2019; Yarkoni, 2020).

Crisis as the perception of an unpredictable event that threatens stakeholder expectations that can seriously affect an organization's performance and produce negative outcomes (Bodrud-Doza et al., 2020; Engelhardt et al., 2021). The definition of crisis that makes the company the object of discussion by the wider community. Meanwhile, a crisis as an unstable condition, in which companies must take action and decisions quickly and appropriately (Ali et al., 2021; Bozkurt et al., 2020; Obiakor \& Adeniran, 2020). Regardless of whatever leadership theory and style exists within an organization, leaders can more fully serve others when they demonstrate Self Leadership (Kin et al., 2018; Sergeeva \& Kortantamer, 2021). Employers prefer workers who can make effective decisions on their own and are able to influence themselves to work effectively (Achim et al., 2019; Coffelt et al., 2019; Patoko \& Yazdanifard, 2014). Self Leadership helps leaders become more self-aware, disciplined, and build stronger relationships. By training people to develop into self-leaders, organizations become more customer-oriented, cost-effective, innovative and effective (Agarwal et al., 2021; Fan et al., 2021; Kartini et al., 2020). In the end, a culture that fosters Self Leadership is a culture that will lead to greatness in an organization. If you are a leader in a time of crisis, it is very important that you practice self-leadership. People will seek your direction and assertiveness. Also, as a leader, it's important to empathize with the anxiety the crisis can cause your people and equip them with self-leadership skills. Self Leadership is the process of building self-direction and selfmotivation, especially in completing and completing important and complex tasks.

Self-leadership involves the determination of people to exert themselves to achieve the selfmotivation and self-direction necessary to behave in the desired way. Self Leadership is developing a sense of who you are, what you can do, where you are going, plus the ability to influence your communications, emotions, and behavior on the way there. Leadership is a cultivated art that begins with Self Leadership (Ariyani, 2021; Kartini et al., 2020; Mudiyantun, 2019). Self Leadership is developing a sense of who you are, what you can do, where you are going, plus the ability to influence your communications, emotions, and behavior on the way there. The pandemic situation that we are currently facing should not be underestimated, in addition to causing physical illness it also affects a person's mental/psychological condition (Dietrich et al., 2020; Odriozola-González et al., 2020; Slovaček \& Čosić, 2020). The importance of Self Leadership for individuals to have control over themselves, considering that in this time of crisis we have to stay at home, work and socialize online. So that all normal activities that used to be carried out will change drastically, Self Leadership plays a role in adapting individuals to adapt to changing circumstances. Self-Leadership also plays a role for a leader, where the leadership during the norm period and the crisis period is certainly different (Durnali, 2020; Mukhtar et al., 2021; Ulum et al., 2020). The new policies that are decided and the implementation of health protocols requires leaders to adapt a new style in escorting organizations/companies out of this crisis condition. Before someone becomes chief, captain, or CEO he must be a leader for himself first. He must be able to determine the goals he wants to achieve, try to achieve them, and be responsible for their achievements. Self-Leadership mastery will have a big impact on oneself and the organization/company, actually the main component in Self-Leadership is how we see, manage and find solutions to problems or crises that we/organizations face (Kumar et al., 2022; Stremersch et al., 2021).

The ability to find solutions and make decisions to save and complete their tasks, critical thinking and problem solving are things that must be possessed by individuals in dealing with crises (Chen et al., 2022; Medeiros et al., 2022). Both of these come from self-control, and the development of an individual's self-leadership. Self-leadership is the main form of leadership. In the context of failure, emotion regulation and self-leadership can work together to help those who have experienced failure move toward recovery and do so more quickly and easily than those who do not engage in these activities (Allal-Chérif et al., 2021; Moran, 2021). Organizational commitment to persist in any problem affects its leadership. With a leader who has good self-leadership, it is very good that the organization is able to get through the crisis it is facing. Self Leadership is important for individuals to thrive in a crisis (Broekema et al., 2019; Chaubey \& Sahoo, 2021). However, the development of self leadership between 1 (one) individual is different from other individuals. Self-Leadership will develop more quickly influenced by the workload, and the sense of responsibility possessed by individuals, where employers and employees have different burdens and responsibilities. Previous research states that the Self Leadership of organizational leaders has greater power than the members of the organization, this is because a leader has the task of managing himself first before managing an organization, this is what differentiates the Self Leadership possessed by the leader (Dang-Pham et al., 2022; Wang et al., 2022). Therefore, the researcher sees something different about the self-leadership of entrepreneurs and non-entrepreneurs during the covid-19 crisis. The purpose of this study was to analyze the differences in Self Leadership in entrepreneurial organizations, entrepreneurial individuals, non-entrepreneurial organizations, and non-entrepreneurial individuals. 


\section{METHODS}

This research is a quantitative research through a cross sectional approach, namely the research variables are measured or collected at one time, meaning that they make observations only once on several variables and at the same time. In this study, the research sample will be classified into 2, namely entrepreneurs and non-entrepreneurs and see the impact on individuals and organizations. The target population of this study is active followers (students/users of Financial Evolution Bali) while the reachable population is active members on Instagram fin.e, so the population in this study is 148 . Active followers who work as entrepreneurs or leaders in their workplaces that are sampled must previously meet the inclusion and exclusion criteria. The inclusion criteria are as follows, Active members who are still active in the Bali Financial Evolution environment, and Active members who are willing to become respondents as evidenced by signing the respondent's consent form. The sample is part of the number and characteristics of the population (Sugiyono, 2018). If the population is large and the researcher is not able to study everything in the population, for example due to limited funds, manpower and time, the researcher can use samples taken from that population (Sugiyono, 2018). The sampling technique in this research is Cluster Sampling which is a group sampling technique. The sample in this study will be classified as entrepreneurs and non-entrepreneurs. The number of samples in this study were 9 indicators x $10=90$ respondents. Data Analysis Techniques is a method or way to process data into information so that the characteristics of the data become easy to understand and also useful for finding solutions to problems, which are mainly problems related to research. Or data analysis can also be interpreted as an activity carried out to change the data resulting from a study into information that can later be used to draw a conclusion.

The purpose of data analysis is to describe data so that it can be understood, and also to make conclusions or draw conclusions about population characteristics based on data obtained from samples, which are usually made on the basis of guessing and testing hypotheses. This research data will be processed using descriptive statistics. Descriptive statistics is a method related to collecting or presenting data to provide useful information. Regarding data with descriptive statistics, researchers need to pay attention to the type of data first. If the researcher has discrete data, the data presentation that can be done is to look for absolute frequency, relative frequency (looking for percentages), and look for measures of central tendency, namely: mode, median and mean (Arikunto, 2006). The analysis used in this study is a different test analysis. Different test analysis is used to find differences, either between two data samples or between several data samples.

\section{RESULTS AND DISCUSSIONS}

\section{Results}

The number of Self Leadership data for organizational entrepreneurs is 25 respondents, while for individual entrepreneurs there are 15 respondents. The average value of Self Leadership for organizational entrepreneurs is 93.00 while individual entrepreneurs are 84.07, thus statistically descriptive it can be concluded that there is a difference in the average Self Leadership between organizational entrepreneurs and individual entrepreneurs. The number of Self Leadership data for organizational non-entrepreneurs is 20 respondents, while for individual non-entrepreneurs as many as 30 respondents. The average value of Self Leadership for organizational non-entrepreneurs is 75.30 while individual non-entrepreneurs is 57.87 , thus statistically descriptive it can be concluded that there is a difference in the average Self Leadership between organizational non-entrepreneurs and individual non-entrepreneurs. The number of Self Leadership data for organizational entrepreneurs is 25 respondents, while for non-entrepreneurs organizations as many as 20 respondents. The average value of Self Leadership for organizational entrepreneurs is 93.00 while non-entrepreneurs organizations are 75.30. Thus, statistically descriptive, it can be concluded that there is a difference in the average Self Leadership between organizational entrepreneurs and individual entrepreneurs. The number of Self Leadership data for individual entrepreneurs is 15 respondents, while for individual non-entrepreneurs as many as 30 respondents. The average value of Self Leadership for organizational entrepreneurs is 84.07 while non-entrepreneurs organizations are 57.87. Thus, statistically descriptive, it can be concluded that there is a difference in the average Self Leadership between organizational entrepreneurs and individual entrepreneurs.

Based on the results of data analysis, it was found that the value of Sig. (2-tailed) of $0.000<0.05$, it can be concluded that $\mathrm{HO}$ is rejected and $\mathrm{H} 1$ is accepted. Thus it can be said that there is a significant difference between Self Leadership in Organizational Entrepreneurs and Individual Entrepreneurs. The value of Sig. (2-tailed) of $0.000<0.05$, it can be concluded that $\mathrm{H} 0$ is rejected and $\mathrm{H} 2$ is accepted. Thus it can be said that there is a significant difference between Self Leadership in Organizational Non-Entrepreneurs and Individual Non-Entrepreneurs. The value of Sig. ( 2 -tailed) of $0.000<0.05$, it can be concluded that H0 is 
rejected and H3 is accepted. Thus it can be said that there is a significant difference between Self Leadership in Organizational Entrepreneurs and Non-Organizational Entrepreneurs. The value of Sig. (2-tailed) of $0.000<0.05$, it can be concluded that $\mathrm{HO}$ is rejected and $\mathrm{H} 4$ is accepted. Thus, it can be said that there is a significant difference between Self Leadership in Organizational Entrepreneurs and Organizational NonEntrepreneurs.

\section{Discussion}

Based on the results of the $t$ test, it shows that the Self Leadership possessed by organizational entrepreneurs and individual entrepreneurs is significantly different so that H1 is accepted. Other research also states that the application of Self Leadership will increase along with the problems, burdens, and responsibilities that are carried out by a person (Kiersch \& Gullekson, 2021; Sergeeva \& Kortantamer, 2021). Organizational entrepreneurs have a burden of responsibility not only to themselves but to their employees and their companies so that they can survive in times of crisis compared to individual entrepreneurs who only have responsibilities to themselves and their companies (Battisti et al., 2022; Niemann et al., 2022). This difference causes a significant difference in the understanding and implementation of Self-Leadership in achieving their respective goals. From the discussion above, it can be concluded that Organizational Entrepreneurs and Individual Entrepreneurs have significant differences in the implementation of Self Leadership in solving the crisis they are facing. Based on the results of the t test, it shows that the Self Leadership possessed by non-entrepreneurs in organizations and non-entrepreneurs in individuals is significantly different so that $\mathrm{H} 2$ is accepted. This is in line with the research, which states that a manager or work group leader has better Self Leadership than its members, because a leader must master all of his potential and continue to move along with the decisions taken, as well as the wishes of his group members in achieve success (Liu et al., 2020; Schyns \& Sczesny, 2010; Sergeeva \& Kortantamer, 2021). Meanwhile, group members in their self-leadership are only able to lead themselves in completing their individual work and do not have confidence in their ability to lead members/coworkers. The ability of managers to manage work and tasks is a self-leadership ability that is not possessed by members/staff (Durnali, 2020; Kin et al., 2018). The development of leadership abilities between managers and employees cannot be equated, due to the level of turnover between managers and employees, where the employee or staff turnover is very high so that Self Leadership ability cannot be improved properly in one place/task (Agarwal et al., 2021; Stremersch et al., 2021). From the discussion above, it can be concluded that Organizational Non entrepreneurs and Individual non entrepreneurs have significant differences in the implementation of Self Leadership in solving the crisis they are facing.

Based on the results of the $t$ test, it shows that the Self Leadership possessed by organizational entrepreneurs and non-entrepreneurs of organizations is significantly different so that H3 is accepted. The difference in leadership between entrepreneurs and managers lies in the way and how the leadership process in an organization (Durnali, 2020; Kiersch \& Gullekson, 2021; Sergeeva \& Kortantamer, 2021). Organizational entrepreneurs tend to motivate their members to be able to complete their work, while a manager tends to direct their members according to the ways he usually does in solving problems. Basically an organizational entrepreneur motivates and inspires his subordinates in helping them complete their work without forcing them to follow the way it works. The sustainability of the company there are several factors that can improve the ability of leaders, namely the ability to prioritize tasks, and being able to lead themselves to keep the company environment stable during a crisis, both of these abilities are owned by the leader, and cannot be owned by members (Kim \& Ji, 2021; Qiao et al., 2022). Each individual's Self Leadership ability is influenced by education factors and the level of education possessed by each individual. Based on the results of his research, it can be said that he tends to have a higher level of education compared to managers/non-entrepreneurs, in terms of business. and maintain the organization (Agarwal et al., 2021; Kiersch \& Gullekson, 2021). From the discussion above, it can be concluded that the Self Leadership possessed by the two is clearly different, where entrepreneurs tend to create a figure who is able to motivate and inspire their members so that it will indirectly help their members in solving the crises they face, but managers tend to make direct directions to their members. members to complete the task or crisis at hand.

Based on the results of the $t$ test, it shows that the Self Leadership possessed by individual entrepreneurs and non-individual entrepreneurs is significantly different so H4 is accepted. Self-influence as a comprehensive perspective concerning the technical aspects of self-leadership, self-leadership has aspects that a person must possess to lead himself, his business, and members of his organization (Avcr \& Kaya, 2021; Lee, 2022). Individual entrepreneurs have the ability to lead themselves and the company to survive and get out of crisis situations, because entrepreneurs have the responsibility for their business to develop and be sustainable, while their employees only lead themselves and are only responsible for the work they provide (Niemann et al., 2022; Ritala et al., 2021; Santos et al., 2020). The obvious difference is that during this crisis, entrepreneurs will be able to make decisions by themselves with strong Self- 
Leadership abilities, while employees tend to wait for directions/instructions from their superiors. The selfleadership strategy of all individuals struggles to help, help independently and competently, the individual practices self-leadership strategies more consistently, but the improvement that each individual gets because of the tasks and problems faced is different (Finn, 2020; Ho \& Nesbit, 2018; Scoresby \& Park, 2021). This is in accordance with the results of research where managers and staff have different responsibilities and different problems, therefore self-leadership owned by managers is better than staff. The leadership abilities possessed by an entrepreneur and staff as individuals are different, because a staff will indirectly imitate the leadership of an individual entrepreneur, because it is one of the inspirations in solving the problem (Moran, 2021; Stremersch et al., 2021). From the above discussion, it can be seen that the implementation of Self Leadership in individual entrepreneurs with individual non-entrepreneurs is very significantly different, where entrepreneurs have the ability to motivate themselves in decision making and are able to see opportunities for success during the pandemic, while employees tend to wait for directions from their managers/company leaders.

This study provides several implications for increasing the understanding of researchers and readers about Self Leadership in providing solutions to crises faced by individuals, especially during the current COVID-19 pandemic. The strength of an individual's Self Leadership will increase the higher the responsibility and burden he has. Indirectly, this research will become a benchmark and reference for how to lead themselves and the organization in times of crisis they face. For example, organizational entrepreneurs who have the biggest burdens and responsibilities among others prove that their Self Leadership is the best among others, their leadership style is able to improve the performance of their companies and their employees' performance because they see a leader who is able to offer solutions to every problem. The limitation of the study is that there are still many variables that can influence and are used to influence and support Self Leadership so that this research becomes more complex and meaningful. In addition, the expansion in the population and sample of the study as well as the level of crisis faced is a good development for further research.

\section{CONCLUSION}

There is a significant difference in Self Leadership between organizational entrepreneurs and individual entrepreneurs, this difference arises because organizational entrepreneurs have different responsibilities and leadership styles and lead organizations that are more complex than individual entrepreneurs. There is a significant difference in Self Leadership between organizational nonentrepreneurs and individual non-entrepreneurs. There is a significant difference in Self Leadership between organizational entrepreneurs and non-entrepreneurs organizations. There is a significant difference in Self Leadership between individual entrepreneurs and individual non-entrepreneurs, this difference can be seen from how the goals to be achieved between the two where an entrepreneur has a goal to maintain his business and develop it while employees or individual non-entrepreneurs tend to only focus on completing their tasks.

\section{REFERENCES}

Achim, N., Badrolhisam, N. I., \& Zulkipli, N. (2019). Employee career decision making: the influence of salary and benefits, work environment and job security. Journal of Academia, 7(1), 41-50.

Agarwal, U. A., Gupta, M., \& Cooke, F. L. (2021). Knowledge hide and seek: Role of ethical leadership, selfenhancement and job-involvement. Journal of Business Research. https://doi.org/10.1016/j.jbusres.2021.11.074.

Ali, S. R. M., Mensi, W., Anik, K. I., Rahman, M., \& Kang, S. H. (2021). The impacts of COVID-19 crisis on spillovers between the oil and stock markets: Evidence from the largest oil importers and exporters. Economic Analysis and Policy. https://doi.org/10.1016/j.eap.2021.11.009.

Allal-Chérif, O., Guijarro-García, M., Ballester-Miquel, J. C., \& Carrilero-Castillo, A. (2021). Being an ethical leader during the apocalypse: Lessons from the walking dead to face the COVID-19 crisis. Journal of Business Research, 133. https://doi.org/10.1016/j.jbusres.2021.05.008.

Amrhein, V., Trafimow, D., \& Greenland, S. (2019). Inferential Statistics as Descriptive Statistics: There Is No Replication Crisis if We Don't Expect Replication. American Statistician, 73(sup1), 262-270. https://doi.org/10.1080/00031305.2018.1543137.

Anastasiou, D., Bragoudakis, Z., \& Giannoulakis, S. (2021). Perceived vs actual financial crisis and bank credit standards: Is there any indication of self-fulfilling prophecy? Research in International Business and Finance, 58. https://doi.org/10.1016/j.ribaf.2021.101486. 
Andersen, T., \& Watkins, K. (2018). The value of peer mentorship as an educational strategy in nursing. Journal of Nursing Education, 57(4), 217-224. https://doi.org/10.3928/01484834-20180322-05.

Ardan, M., Rahman, F. F., \& Geroda, G. B. (2020). The influence of physical distance to student anxiety on COVID-19, Indonesia. Journal of Critical Reviews, 7(17), 1126-1132. https://doi.org/10.31838/jcr.07.17.141.

Arikunto, S. (2006). Metodologi Penelitian. Jakarta: Bina Aksara.

Ariyani, D. (2021). Principal's Innovation and Entrepreneurial Leadership to Establish a Positive Learning Environment. European Journal of Educational Research, 10(1), 63-74. https://doi.org/10.12973/eu-jer.10.1.63.

Avcl, N., \& Kaya, G. (2021). The relationship of learned resourcefulness with self-leadership skills: A study with nurse and midwife students. Nurse Education Today, 107. https://doi.org/10.1016/j.nedt.2021.105125.

Battisti, S., Agarwal, N., \& Brem, A. (2022). Creating new tech entrepreneurs with digital platforms: Metaorganizations for shared value in data-driven retail ecosystems. Technological Forecasting and Social Change, 175. https://doi.org/10.1016/j.techfore.2021.121392.

Bodrud-Doza, M., Shammi, M., Bahlman, L., Islam, A. R. M., \& Rahman, M. (2020). Psychosocial and socioeconomic crisis in Bangladesh due to COVID-19 pandemic: a perception-based assessment. Frontiers in Public Health, 8, 341. https://doi.org/10.3389/fpubh.2020.00341.

Bozkurt, A., Jung, I., Xiao, J., Vladimirschi, V., Schuwer, R., Egorov, G., Lambert, S. R., \& Al-Freih, M. (2020). A global outlook to the interruption of education due to COVID-19 Pandemic: Navigating in a time of uncertainty and crisis. Asian Journal of Distance Education, 15(1). https://doi.org/10.5281/zenodo.3878572No Title.

Broekema, W., Porth, J., Steen, T., \& Torenvlied, R. (2019). Public leaders' organizational learning orientations in the wake of a crisis and the role of public service motivation. Safety Science, 113. https://doi.org/10.1016/j.ssci.2018.11.002.

Chan, T. K., \& Abdul-Aziz, A. R. (2017). Financial performance and operating strategies of Malaysian property development companies during the global financial crisis. Journal of Financial Management of Property and Construction, 22(2). https://doi.org/10.1108/JFMPC-02-2016-0009.

Chaubey, A., \& Sahoo, C. K. (2021). Assimilation of business intelligence: The effect of external pressures and top leaders commitment during pandemic crisis. International Journal of Information Management, 59. https://doi.org/10.1016/j.ijinfomgt.2021.102344.

Chen, Q., Huang, Q., Liu, C., \& Wang, P. (2022). Career incentives of local leaders and crisis response: A case study of COVID-19 lockdowns in China. European Journal of Political Economy. https: //doi.org/10.1016/j.ejpoleco.2022.102180.

Coffelt, T. A., Grauman, D., \& Smith, F. L. M. (2019). Employers' Perspectives on Workplace Communication Skills: The Meaning of Communication Skills. Business and Professional Communication Quarterly, 82(4), 418-439. https://doi.org/10.1177/2329490619851119.

Dang-Pham, D., Kautz, K., Hoang, A.-P., \& Pittayachawan, S. (2022). Identifying information security opinion leaders in organizations: Insights from the theory of social power bases and social network analysis. Computers \& Security, 112. https://doi.org/10.1016/j.cose.2021.102505.

Dietrich, N., Kentheswaran, K., Ahmadi, A., Teychene, J., Bessiere, Y., Alfenore, S., Laborie, S., Bastoul, D., Loubiere, K., Guigui, C., Sperandio, M., Barna, L., Paul, E., Cabassud, C., Line, A., \& Hebrard, G. (2020). Attempts, successes, and failures of distance learning in the time of covid-19. Journal of Chemical Education, 97(9), 2448-2457. https://doi.org/10.1021/acs.jchemed.0c00717.

Durnali, M. (2020). The effect of self-directed learning on the relationship between self-leadership and online learning among university students in Turkey. Tuning Journal for Higher Education, 8(1), 129-165. https://doi.org/10.18543/tjhe-8(1)-2020pp129-165 Received.

Engelhardt, N., Krause, M., Neukirchen, D., \& Posch, P. N. (2021). Trust and stock market volatility during the COVID-19 crisis. Finance Research Letters, 38. https://doi.org/10.1016/j.frl.2020.101873.

Fan, X., Li, J., Mao, Z. (Eddie), \& Lu, Z. (2021). Can ethical leadership inspire employee loyalty in hotels in China? -From the perspective of the social exchange theory. Journal of Hospitality and Tourism Management, 49. https://doi.org/10.1016/j.jhtm.2021.11.006.

Finn, P. (2020). Organising for entrepreneurship: How individuals negotiate power relations to make themselves entrepreneurial. Technological Forecasting and Social Change, 166. https://doi.org/10.1016/j.techfore.2021.120610.

Hao, F., Xiao, Q., \& Chon, K. S. (2020). COVID-19 and China's Hotel Industry: Impacts, a Disaster Management Framework, and Post-Pandemic Agenda. International Journal of Hospitality Management, 90. https://doi.org/10.1016/j.ijhm.2020.102636. 
Ho, J., \& Nesbit, P. L. (2018). Personality and work outcomes: A moderated mediation model of selfleadership and gender. International Journal of Management Excellence, 10(2). https://doi.org/10.17722/ijme.v10i2.416.

Kartini, D., Kristiawan, M., \& Fitria, H. (2020). The Influence of Principal's Leadership, Academic Supervision, and Professional Competence toward Teachers' Performance. International Journal of Progressive Sciences and Technologies, 20 No. 1 A(April), 156-164.

Kiersch, C., \& Gullekson, N. (2021). Developing character-based leadership through guided self-reflection. The International Journal of Management Education, 19(3). https://doi.org/10.1016/j.ijme.2021.100573.

Kim, S., \& Ji, Y. (2021). Positive ripple effects of corporate leaders' CSR donations amid COVID-19 on corporate and country reputations: Multi-level reputational benefits of CSR focusing on Bill Gates and Jack Ma. Public Relations Review, 47(4). https://doi.org/10.1016/j.pubrev.2021.102073.

Kin, T. M., Abdull Kareem, O., Nordin, M. S., \& Wai Bing, K. (2018). Principal change leadership competencies and teacher attitudes toward change: the mediating effects of teacher change beliefs. International Journal of Leadership in Education, 21(4), 427-446. https://doi.org/10.1080/13603124.2016.1272719.

Klebe, L., Felfe, J., \& Klug, K. (2021). Mission impossible? Effects of crisis, leader and follower strain on health-oriented leadership. European Management Journal. https://doi.org/10.1016/j.emj.2021.07.001.

Kumar, D., Upadhyay, Y., Yadav, R., \& Goyal, A. K. (2022). Psychological capital and innovative work behaviour: The role of mastery orientation and creative self-efficacy. International Journal of Hospitality Management, 102. https://doi.org/10.1016/j.ijhm.2022.103157.

Lee, M. K. (2022). Decisional balance, self-leadership, self-efficacy, planning, and stages of change in adopting exercise behaviors in patients with stomach cancer: A cross-sectional study. European Journal of Oncology Nursing, 56. https://doi.org/10.1016/j.ejon.2021.102086.

Liu, Y., Bellibaş, M. Ş., \& Gümüş, S. (2020). The effect of instructional leadership and distributed leadership on teacher self-efficacy and job satisfaction: Mediating roles of supportive school culture and teacher collaboration. Educational Management Administration and Leadership, 1-24. https://doi.org/10.1177/1741143220910438.

Medeiros, K. E., Crayne, M. P., Griffith, J. A., Hardy, J. H., \& Damadzic, A. (2022). Leader sensemaking style in response to crisis: Consequences and insights from the COVID-19 pandemic. Personality and Individual Differences, 187. https://doi.org/10.1016/j.paid.2021.111406.

Moran, T. (2021). The Secret of Serotinous Leadership:: The Pandemic Crisis Changed Care Models, But Only After Leaders Changed Their Minds About Them. Nurse Leader, 19(5). https: //doi.org/10.1016/j.mnl.2021.06.003.

Mudiyantun, Y. (2019). The Investigation Of Situational Leadership, And Work Motivation On Kindergarden Teacher Performance. Jurnal Kepemimpinan Pendidikan, 2(1). https://doi.org/10.22236/jkpuhamka.v2i1.3814.

Mukhtar, El-Widdah, M., \& Padli, M. (2021). The Impression of Kiai's Leadership In Managing Islamic Boarding Schools. International Journal of Educational Review, 3(1). https://doi.org/https://doi.org/10.33369/ijer.v3i1.11689.

Niemann, C. C., Mai, R., \& Dickel, P. (2022). Nurture or nature? How organizational and individual factors drive corporate entrepreneurial projects. Journal of Business Research, 140. https://doi.org/10.1016/j.jbusres.2021.11.065.

Obiakor, T., \& Adeniran, A. (2020). Covid-19: Impending Situation Threatens To Deepen Nigeria ' S Education Crisis. Center For The Study of The Economies Of Africa.

Odriozola-González, P., Planchuelo-Gómez, Á., Irurtia, M. J., \& de Luis-García, R. (2020). Psychological effects of the COVID-19 outbreak and lockdown among students and workers of a Spanish university. Psychiatry Research, 290. https://doi.org/10.1016/j.psychres.2020.113108.

Paramita, I. B. G., \& Putra, I. G. G. P. A. (2020). New Normal Bagi Pariwisata Bali Di Masa Pandemi Covid 19. Jurnal Ilmiah Pariwisata Agama Dan Budaya, 5(2). https://doi.org/10.25078/pba.v5i2.1723.

Patoko, N., \& Yazdanifard, R. (2014). The Impact of Using Many Jargon Words, while Communicating with the Organization Employees. American Journal of Industrial and Business Management, 04(10), 567572. https://doi.org/10.4236/ajibm.2014.410061.

Pedroza-Gutiérrez, C., Vidal-Hernández, L., \& Rivera-Arriaga, E. (2021). Adaptive governance and coping strategies in the Yucatan Peninsula coasts facing COVID-19. Ocean \& Coastal Management, 212. https://doi.org/10.1016/j.ocecoaman.2021.105814. 
Qiao, P., Long, Y., Fung, H.-G., \& Kao, E. H.-C. (2022). Narcissistic leaders and corporate cash Holdings: Evidence in China. The North American Journal of Economics and Finance, 59. https://doi.org/10.1016/j.najef.2021.101567.

Richard, K., Noujaim, M., Thorndyke, L. E., \& Fischer, M. A. (2019). Preparing Medical Students to Be Physician Leaders: A Leadership Training Program for Students Designed and Led by Students. MedEdPORTAL: The Journal of Teaching and Learning Resources, 15, 10863. https://doi.org/10.15766/mep_2374-8265.10863.

Ritala, P., Baiyere, A., Hughes, M., \& Kraus, S. (2021). Digital strategy implementation: The role of individual entrepreneurial orientation and relational capital. Technological Forecasting and Social Change, 171. https://doi.org/10.1016/j.techfore.2021.120961.

Santos, G., Marques, C. S., \& Ferreira, J. J. M. (2020). Passion and perseverance as two new dimensions of an Individual Entrepreneurial Orientation scale. Journal of Business Research, 112. https://doi.org/10.1016/j.jbusres.2020.03.016.

Sari, D. H., Khairiyah, N. M., \& Ismawanto, T. (2021). Efektivitas Pelaksanaan Restrukturisasi Kredit Sebagai Strategi Penurunan Kredit Bermasalah Selama Pandemic Covid-19 Pegadaian Kanwil Balikpapan. Jurnal Studi Management Dan Bisnis, 8(2). https://doi.org/10.21107/jsmb.v8i2.12589.

Schyns, B., \& Sczesny, S. (2010). Leadership attributes valence in self-concept and occupational self-efficacy. Career Development International, 15(1), 78-92. https://doi.org/10.1108/13620431011020907.

Scoresby, R. B., \& Park, H. (2021). The joint effects of individual and firm level knowledge attributes on inventor mobility to entrepreneurial and established firms. Journal of Business Research, 133. https://doi.org/10.1016/j.jbusres.2021.04.059.

Sergeeva, N., \& Kortantamer, D. (2021). Enriching the concept of authentic leadership in project-based organisations through the lens of life-stories and self-identities. International Journal of Project Management, 39(7). https://doi.org/10.1016/j.ijproman.2021.09.001.

Slovaček, K. A., \& Čosić, G. (2020). The Role of Parents during the COVID19 Pandemic in Croatia. Studies in Educational Management, 8(8), 9-17. https://doi.org/10.32038/sem.2020.08.02.

Stremersch, S., Camacho, N., Keko, E., \& Wuyts, S. (2021). Grassroots innovation success: The role of selfdetermination and leadership style. International Journal of Research in Marketing. https://doi.org/10.1016/j.ijresmar.2021.10.003.

Sugiyono. (2018). Metode Penelitian Pendidikan Pendekatan Kuantitatif, Kualitatif dan R\&D. Alfa Beta.

Syahria, N. (2020). Teaching During Covid-19 Pandemic: What Should Educators Do To Save Nations' Educational Crisis?Lectio: LECTIO: Journal of Language and Language Teaching, 1(1), 29-41.

Tao, W., Lee, Y., Sun, R., Li, J.-Y., \& He, M. (2022). Enhancing Employee Engagement via Leaders' Motivational Language in times of crisis: Perspectives from the COVID-19 outbreak. Public Relations Review, 48(1). https: //doi.org/10.1016/j.pubrev.2021.102133.

Tuan, L. T. (2021). Leader crisis communication and salesperson resilience in face of the COVID-19: The roles of positive stress mindset, core beliefs challenge, and family strain. Industrial Marketing Management. https://doi.org/10.1016/j.indmarman.2021.12.006.

Ulum, M. B., Sarwoko, E., \& Yuniarinto, A. (2020). Kepemimpinan Kepala Sekolah Dan Kinerja Guru: Peran Mediasi Motivasi Kerja. Jurnal Administrasi Dan Manajemen Pendidikan, 3(4), 299-307. https: //doi.org/10.17977/um027v3i42020p299.

Van Lancker, W., \& Parolin, Z. (2020). COVID-19, school closures, and child poverty: a social crisis in the making. The Lancet Public Health, 5(5), e243-e244. https://doi.org/10.1016/S24682667(20)30084-0.

Wang, X., Liu, Z., Wen, X., \& Xiao, Q. (2022). An implicit leadership theory lens on leader humility and employee outcomes: Examining individual and organizational contingencies. Tourism Management, 8. https://doi.org/10.1016/j.tourman.2021.104448.

Wei, Y., Qin, S., Li, X., Zhu, S., \& Wei, G. (2019). Oil price fluctuation, stock market and macroeconomic fundamentals: Evidence from China before and after the financial crisis. Finance Research Letters, 30. https://doi.org/10.1016/j.frl.2019.03.028.

Yarkoni, T. (2020). The generalizability crisis. Behavioral and Brain Sciences. https://doi.org/10.1017/S0140525X20001685. 